\title{
THE EFFECT OF EMETINE ON THE WHITE BLOOD CORPUSCLES.
}

\author{
By Benj. H. Schlomovitz, B. S., M. A., Chicazo, Illinois.
}

(From Research Laboratories, Department of Materia Medica and Therapeutics, College of Dentistry, University of Illinois.)

(Read before the National Dental Association at Its Twenty-flrst Annual Session, New York City, N. Y., October 23-26, 1917.)

I $T$ IS well known that from the viewpoint of the biologist the amoeba and the leucocyte, especially the polymorphonuclear cell and the endothelial leucocyte, are very closely related-particularly from the functional standpoint. On the basis of this fact it would seem possible to influence the behavior of these cells similarly. The application of emetine hydrochloride in conditions where amoeba were directly or indirectly involved, as well as the known amebicidal effect of emetine in prescribed experimental procedure suggested to us, that beyond the apparent toxic results of emetine in larger doses there must be either a transitory or temporary effect on the leucocytes in the bloodstream or at their points of origin, even when using therapeutic doses. It is true that the specific toxicity of emetine extends in a smaller degree to ordinary forms of amoeba, but there ought to be some leucotoxic action for emetine.

If emetine is leucotoxic, it would not be unique, for it is established fact that there are drugs that can be lymphotoxic and leucotoxic (Binz, Heinecke, Chassavant, Wilkinson, Maurel, Heinz, Roth, Bunting, Sherrington, Weiskotten Schwartz and Steensland, Selling, and others). We were unable to find any studies of the leucotoxic action of emetine except those of Maurel and Nielsen. Heinz, in his Handbuch der experimentelle Pathologie and Pharmakologie reviews the literature up to about 1900 on drug action related to white blood cells. Since 1903, such data if published would be reviewed in the Folia Haematologica. In addition we checked the files of the Societe de Biologie, and Journal of Pharmacology and Experimental Therapeutics, as well as the principal papers on the pharmacology of emetine.

Maurel has studied the behavior of leucocytes since 1881 . His method with emetine consisted in adding it in varying amounts-0.125 to 2.0 gms. to 100 grams of blood, human or rabbits. $\mathrm{He}$ states that the white-blood cells lose their activity and vitality while the red-blood cells apparently remain unaltered. Nielsen found no change in the blood cell-count of three rabbits after injecting 6 mgms. or repeatedly injecting $4.5 \mathrm{mgms}$. daily in rabbits weighing about 1.242 kilograms. We believe the counts were made too late after injecting.

The following data may have a bearing on this work. Meyer and Williams showed that emetine decreases the $\mathrm{CO}_{2}$ content in the blood. Pellini and Wallace demonstrated an increase in nitrogenous metabolism. Magendie and Pelletier's work in 1817 that there is an 
hyperaemia and inflammation of the gastrointestinal tract following emetine administration has been confirmed repeatedly (Pecholier, Duckworth, Podwyssotzki, and others). It is known that such irritation of the gastrointestinal tract may be associated with a leucocytosis. Abl has been shown that uric acid excretion can be influenced by drugs. With ipecac, the mother substance of emetine, he obtained an increase of 42 and 48 per cent. in one case, and a slight decrease in a second case. This is significant when we learn that an increased uric acid secretion accompanies a leucocytosis. Other questions that arise are the following,-Does emetine mobilize the leucocytes chemotactically? Does the fall in blood-pressure influence the white-cell count? Does emetine influence the temperature which in turn is said to be accompanied by white-cell changes? Does emetine show a diphasic phenomenon on the leucocytes as benzol and other drugs? Does emetine produce structural changes in the leucocyte as it does in the amoeba? Is the blood picture the same thruout the circulation as it is in the peripheral circulation? Is emetine a specific poison to the leucogenetic centers?

We counted the white blood cells after injecting emetine hydrochloride, in rabbits and man. There is no such strikingly average white-cell correct for rabbits as for man, as seen by the following figures:

Maurel, extremes, 5270-10230.

Galland and Goodall, 10500.

Burnett, 8500 .

Wells, extremes, 3300-14650; average, 9000.

Ewing, 8500 .

(White blood corpuscles in rabbitsSoewitt, Hirschfeld, Hesse, Bezancon and Sabbe, Tallquist-Willebrand, Furno, Brincherhoff and Tyzzer, etc.) We obtained the same results. However, for an individual rabbit there is a fairly accurate average. Further, in the rabbit there seems to be no distinct period of "alimentary lecocytosis," so that the changes produced by emetine should occur shortly after injection, or else affect the body by producing phenomena similar to tolerance.

The rabbits were weighed daily, and the temperature was determined before experimenting, averaging 102-103 degrees. The blood was usually taken from the ear, and the injections were either intravenous or intramuscular. In man, the injections were intramuscular, in the buttocks.

The following are examples of the results obtained:

I-A fresh solution of emetine $\mathrm{HC} 1$ was used. 2 mgms. per kilogram intravenously.

Rabbit No. 91- W. B. C.

Before injection ....... 6250

One hour after injection... 7700

Two hours after injection.. 9900

Second day .......... 6350

Injected 2 mgms. per kilo

23 min. after ......... 11100

3 hours, 45 min. after.... 9300

Third day ......... 8600

Rabbit No. 98- W. B.C.

First day ........... 12550

Second day .......... 11950

Injected.

15 min. after......... 13700

$1 \mathrm{hr}, 8 \mathrm{~min}$. after....... 23100

4 hrs., 8 min. after. . . . . . 14200

Rabbit No. 100

First day ........... 10250

Second day .......... 10200

Injected.

21 min. after ........ 8350

1 hr., 21 min. after...... 9485

II-Series with old solution of emetine $\mathrm{HC1}$. Intravenous injections.

Rabbit No. 99-

Normal ............ 8450

Injected.

1 hr., 5 min. after...... 5850

$1 \mathrm{hr} ., 50 \mathrm{~min}$. after..... 8050 
Rabbit No. 98 A-

Normal .......... 5150

Injected.

25 min. after ......... 7200

55 min. after ........ 6500

III Series-rabbits previously used for emetine injections.

Rabbit No. 97-

First day-Leucopenia.

Third day-Leucocytosis.

Eighth day-Leucopenia.

IV Series-intramuscular injections.

Rabbit No. 88-Leucocytosis.

Rabbit No. 89-Leucopenia.

V Series on Man-Intramuscular injections of $30 \mathrm{mgms}$. - no food for 4 to 7 hours. Blood taken from lobe of the ear.

Mr. B.-Apparently healthy.

First day-Leucopenia in $30 \mathrm{~min}$.

Second day-Leucopenia.

Third day-No change.
Fourth day-No change. tion.

Fifth day-No count and no injec-

Sixth day-Leucopenia marked.

Seventh day-Leucopenia less marked.

Mr. M.-Apparently healthy.

First day-Slight drop.

Second day-Same.

Third day-Same.

Fourth day-No change.

Fifth day-No count and no injection.

Sixth day-Slight drop.

Seventh day-No count and no injection.

Eighth day-Slight drop.

We are not attempting to draw any conclusions as yet, but the tendency seems to be a leucopenia in the peripheral circulation following emetine hydrochloride injection. How this is produced is another problem, but we believe that emetine is a leucotoxin. 